\title{
Influence of nanomaterials on stem cell differentiation: designing an appropriate nanobiointerface
}

REVIEW

International Journal of Nanomedicine

2 May 2012

Number of times this article has been viewed

loana Ilie'

Razvan Ilie ${ }^{2}$

Teodora Mocan ${ }^{3}$

Dana Bartos ${ }^{4}$

Lucian Mocan ${ }^{4}$

'Department of Endocrinology,

2Department of Microbiology,

${ }^{3}$ Department of Physiology,

"Third Surgery Clinic, Department of Nanomedicine, "luliu Hatieganu"

University of Medicine and Pharmacy,

Cluj-Napoca, Romania
Correspondence: Lucian Mocan and Razvan llie

3rd Surgery Clinic, Department of Nanomedicine, "Iuliu Hatieganu" University of Medicine and Pharmacy, |9-2| Croitorilor Street,

Cluj-Napoca, Romania

Tel +40264439696

Fax +40264439696

Email mocanlucian@yahoo.com; razvan. ilie@umfcluj.ro
Abstract: During the last decade, due to advances in functionalization chemistry, novel nanobiomaterials with applications in tissue engineering and regenerative medicine have been developed. These novel materials with their unique physical and chemical properties are bioactive hierarchical structures that hold great promise for future development of human tissues. Thus, various nanomaterials are currently being intensively explored in the directed differentiation of stem cells, the design of novel bioactive scaffolds, and new research avenues towards tissue regeneration. This paper illustrates the latest achievements in the applications of nanotechnology in tissue engineering in the field of regenerative medicine.

Keywords: nanotechnology, nanomaterials, tissue engineering, regeneration, stem cell differentiation

\section{Introduction}

Tissue engineering and regenerative medicine have been constantly developing of late due to the major progress in cell and organ transplantation, as well as advances in materials science and engineering. Isolated from a variety of embryonic, fetal, and adult tissues, stem cell populations have the advantage of being significantly proliferative and, therefore, could be extremely efficient in the treatment of presently incurable diseases in the near future. Moreover, their unique characteristics related to the differentiation, regeneration, development, remodeling, and replenishment of aged and diseased tissues make them perfect candidates in this area. In a very easy and simple way, stem cells can be conceptually divided into two types: embryonic stem cells (ESCs) - derived from a very early embryo and adult stem cells - found in postnatal tissues, of both the body (bone marrow [BM], adipose tissue, etc) and the umbilical cord (UC). ${ }^{1}$

Their high self-renewal capacity and pluripotency in differentiating into derivatives of all germ layers in vitro and in vivo have made embryonic stem cells leading candidates for tissue engineering research and regenerative medicine, covering a wide range of therapeutic areas, including the treatment of several neurological and cardiac disorders, diabetes, hematopoietic diseases, liver diseases, and lung diseases. However, in addition to ethical and political concerns, their clinical application is severely limited by their lack of accessibility and the difficulties that impede purification and manipulation techniques, as well as concerns related to the risk of teratoma formation. ${ }^{2}$

On the other hand, mesenchymal stem cells, one of the many types of adult stem cells, also have a high self-renewal capability and expansive potential ex 
vivo. Furthermore, they are more versatile in changing their phenotype during differentiation, are present in large numbers in adults, and are also relatively easy to isolate and culture, features which make them suitable for tissue regeneration and cell-based therapy. ${ }^{3}$ Because mesenchymal stem cells of multiple adult vertebrate species originate from extra embryonic mesoderm, their capacity to differentiate into adipogenic, chondrogenic, and osteogenic lineages as well as into myogenic and fibroblastic lineages has been extensively studied. ${ }^{2,4}$ Further, controversial data indicate that mesenchymal stem cells may give rise to sarcomeric muscle (skeletal and cardiac) cells, endothelial cells, and even cells of non-mesodermal origin, such as hepatocytes, neural cells, and epithelial cells. ${ }^{5}$ However, in contrast, Yang et $\mathrm{al}^{6}$ concluded that the mechanism underlying the promoting effect on the regeneration of several corticospinal axons and locomotor recovery after spinal cord transection in the rat following human umbilical cord mesenchymal stem cell transplantation is likely via the release of more cytokines or growth factors from undifferentiated stem cells rather than the differentiation of these cells into neuronal or glial cells. In support of this, Rossignol et al also suggested that recovery of motor function in a 3-nitropropionic acid rat model of Huntington's disease was likely due to release of trophic factors from bone marrow mesenchymal stem cells because very few transplanted mesenchymal stem cells demonstrated evidence of transdifferentiation. ${ }^{7}$ Moreover, in spite of the fact that some researchers have successfully transformed Wharton's jelly-derived human umbilical cord blood mesenchymal stem cells into cardiomyocytes using 5 -azacytidine or cardiomyocyte-conditioned medium and noted slight spontaneous beating, ${ }^{2}$ others have failed to generate cardiomyocyte-like cells from human umbilical cord blood mesenchymal stem cells, either spontaneously or after use of various protocols, including addition of chemicals (5-azacytidine and dimethyl sulfoxide), growth factors, Wnt signaling activators, and direct contact with neonatal rat cardiomyocytes. ${ }^{8,9}$ Though mesenchymal stem cells have been demonstrated to differentiate in culture into several distinct mesenchymal lineages and possibly into other cell types, including astrocytes, oligodendrocytes, neuronal cells, cardiomyocytes, pancreatic $\beta$-cells, and hepatocytes, ${ }^{4,10}$ poor engraftment and limited differentiation under in vivo conditions are drawbacks that limit their therapeutic efficiency. ${ }^{11}$ Consequently, better monitoring and evaluation tools for engineered tissues, and especially for new biomaterials, are needed to facilitate tissue growth and stem cell differentiation.
Nanomaterials have unique advantages in controlling stem cell function and in tissue regeneration (Figure 1) due to their biomimetic characteristics and special biological and mechanical properties. ${ }^{12}$ Researchers have focused on application of nanomaterials in the biomedical field because of the fact that provision of an appropriate nanobiointerface can secure the control of cellular behavior, and, therefore, optimal tissue regeneration. ${ }^{13-16}$ Moreover, research activity in this field has been fuelled by recent advances in nanomaterial preparation, increasing awareness on the part of materials science and tissue engineering researchers regarding the potential role of stem cells in regenerative medicine, and advances in stem cell biology. Most of the research has focused on development of novel nanoparticles or nanotubes for stem cell imaging ${ }^{17}$ and for potential delivery of chemotherapeutic agents to tumors, respectively. ${ }^{18}$ However, these nanoparticles have several other potential applications, ie, as intracellular drug carriers to control stem cell differentiation and as biosensors to monitor intracellular levels of relevant biomolecules/ enzymes in real time. The nanoparticles most commonly used in stem cell research are organic and inorganic nanoparticles, ${ }^{19,20}$ liposomes, ${ }^{21}$ polyplexes, ${ }^{22}$ quantum dots, ${ }^{23}$ and carbon nanotubes. ${ }^{24,25}$ In addition, some synthetic materials, such as polylactide-co-glycolide (PLGA), poly-caprolactone, and natural materials, such as collagen and chitosan, can be used as nanoparticles in medical applications. The following are some potential applications of these nanoparticles in stem cell research: non-invasive tracking of stem cells and progenitor cells transplanted in vivo; intracellular delivery of DNA, RNA interference molecules, proteins, peptides, genes, ${ }^{26}$ and small drugs for stem cell differentiation or survival, and biosensing of the physiological state of stem cells. ${ }^{25}$ Therefore, osteogenic or chondrogenic differentiation of stem cells has been obtained by intracellular delivery of growth factors mediated by nanoparticles. ${ }^{27}$ Stem cells were also transfected using nanoparticles encapsulated with plasmid DNA encoding bone morphogenetic protein (BMP)2, which induce ondotogenic or osteogenic differentiation. ${ }^{28,29}$

\section{Nanomaterials for controlling differentiation of stem cells}

Tissue regeneration is tightly related to the process of controlling adhesion and differentiation of stem cells. The ability to deliver biomolecules, including proteins, growth factors, and small chemicals, via an intracellular route presents an excellent tool to control the differentiation 


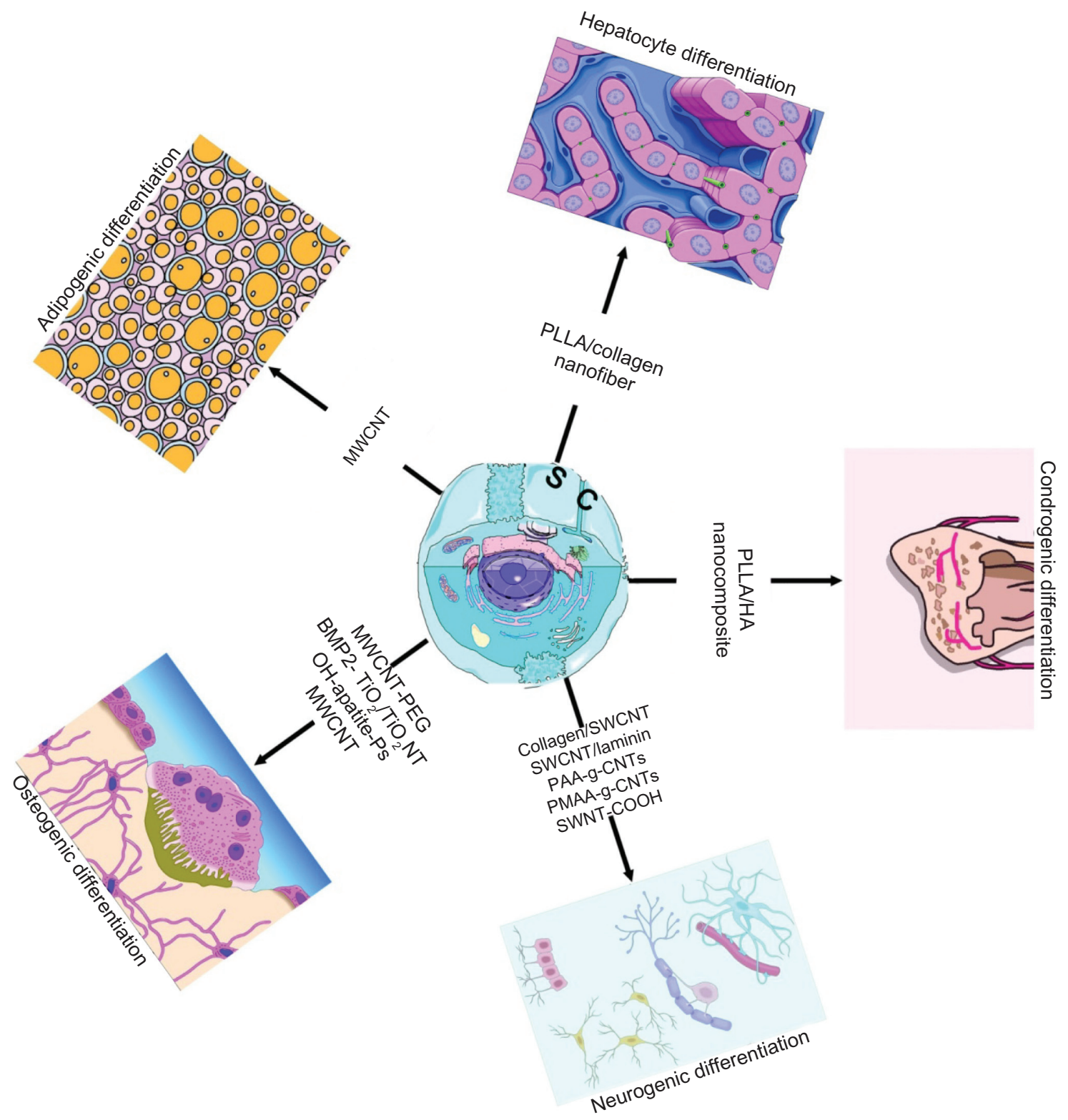

Figure I Stem cell differentiation mediated by bionanomaterials with applications in regenerative medicine.

of stem cells. Some of these biomolecules/chemicals have poor solubility, can be quickly cleaved by cellular enzymes, and have various side effects when administered systemically.

Biodegradable and biocompatible nanoparticles which have the ability to target stem cells and release their payload in the cytoplasm, followed by activation of signaling cascades, are likely to be the focus of future research. For example, Ferreira et al have already reported a new approach for the delivery of vascular growth factors in human embryonic stem cells, in which growth factor-releasing particles are incorporated in human embryoid bodies. ${ }^{20}$ They showed that incorporation of these polymeric biodegradable particles had a minimal effect on cell viability and proliferation, but had a large impact on differentiation. The effect on vascular differentiation of particles containing growth factors was, in some cases, even higher than that observed by exposing embryoid bodies to large extrinsic doses of the same growth factors. This unique feature enables nanoparticles to be used as a platform to deliver growth factors and other biomolecules within stem cells. ${ }^{25}$ In response to the strong demand for development of stem cell differentiation, carbon nanotubes have emerged as a promising material for tissue engineering, due to their tremendous strength, ultralight weight, and high stability, as well as their ability to become very flexible after suitable functionalization. ${ }^{30,31}$ 


\section{Differentiation into mesenchymal-} osteogenic, adipogenic, chondrogenic lineage

Mesenchymal stem cells

\section{Bone regeneration}

In the geriatric field, osteoporosis, osteoarthritis, periodontitis, and other skeletal diseases are the major targets of regenerative medicine. As the average age of the population rises, the incidence of these diseases also continues to rise, and although they are not usually life-threatening, they often severely affect the quality of life of elderly patients. Moreover, vertebral compression fractures, the most common fragility fractures, account for approximately 700,000 injuries per year. Given that open surgery involves a considerable risk of morbidity and implant failure in the osteoporotic patient population, a new minimally invasive biological solution to vertebral bone repair is needed..$^{32}$ Although substantial progress in regenerative medicine, bone scaffolds, and cartilage tissue engineering has been made in the past few years, it still falls short of clinical requirements.

Specific bioactive growth factors, nutrients, and environmental cues can direct human mesenchymal stem cell differentiation into mesodermal lineages, including osteoblasts, chondrocytes, and adipocytes. ${ }^{33}$ In vivo studies have shown that bone repair processes in adults resemble normal development of the skeleton during embryogenesis. Recent data suggest that osteoclasts and mesenchymal stem cells are the main cells involved in bone formation, whereas parathyroid hormone-related protein, Wnt, mitogen-activated protein kinases, and BMPs, including BMP2 and BMP7, represent crucial signaling proteins in these processe ${ }^{34}$ and can induce osteoblast-like genes and matrix mineralization in primary human mesenchymal stem cell culture. ${ }^{12,35}$ Bone and cartilage tissue engineering is emerging as a promising therapeutic tool that aims both to repair damaged tissues and to regenerate them fully by combining cells, biomaterials mimicking extracellular matrix (scaffolds), and regulatory signals. ${ }^{36}$

The mechanical profile of bone is the most important factor to consider when designing a material to be used as a bone scaffold. ${ }^{37}$ Consequently, because of their excellent mechanical strength, carbon nanotubes and carbon nanofibers have been the focus of many studies related to the use of these nanostructures as reinforcing agents in composite materials $\mathrm{s}^{38,39}$ and especially in bone scaffolds. ${ }^{40-42}$ Additionally, singlewalled carbon nanotubes (SWCNTs) are less dense than other metallic or ceramic-based bone scaffolds used in orthopedics (eg, titanium, stainless steel, alumina), so will produce lighter scaffolds with very high strength.
Pristine SWCNTs do not have any inherent properties in order to support new bone growth. As previously mentioned, carbon nanotubes/carbon nanofibers can be functionalized with different side groups which can improve the biocompatibility properties ${ }^{43}$ and/or mechanical strength ${ }^{44}$ in tubebased/fiber-based scaffolds. ${ }^{42}$ Therefore, conjugating carbon nanotubes with functional groups that attract calcium cations enables carbon nanotubes to be used as scaffolds for bone regeneration. ${ }^{43}$ For example, SWCNTs were functionalized with poly(aminobenzene sulfonic acid) (PABS) using amidation of the carboxylic acid groups on SWCNTs (CNT-COOH) with amines (PABS) through an acyl chloride intermediate (CNT-COCl): SWCNT-COOH $\rightarrow$ SWCNT-COCl $\rightarrow$ SWCNT-PABS. ${ }^{43}$ Thin films of either SWCNT-COOH or SWCNT functionalized with PABS (SWCNT-PABS) were deposited on glass slides and soaked for 7 days in a solution of $\mathrm{CaCl}_{2}$ and $\mathrm{Na}_{2} \mathrm{HPO}_{4}$. At the end of this period, a large amount of "plate-shaped hydroxyapatite crystals" could be identified throughout the whole surface of the thin SWCNT-PABS films. Additionally, researchers found that the thickness of the hydroxyapatite layer was $2.4 \mu \mathrm{m}$, growing to a thickness of $3.5 \mu \mathrm{m}$ after 14 days, whereas thin SWCNT-COOH films showed no increase in mineralization between 7 and 14 days. The experiment thus offered a method of producing carbon nanotubes which support hydroxyapatite mineralization by functionalizing the tubes with negatively charged groups (ie, PABS). ${ }^{42}$

PLGA, a copolymer of polylactic acid and polyglycolic acid, is a biodegradable polyester. Its variable molecular weight and composition enables it to be rationally designed to control the release kinetics of encapsulated therapeutic agents. The incorporation of osteoconductive nanohydroxyapatite into PLGA can improve the mechanical and biological properties of the scaffold and moderate the degradation rate. ${ }^{45,46}$ Furthermore, nanohydroxyapatite-PLGA scaffolds proved to be associated with higher rabbit mesenchymal stem cell growth and alkaline phosphatase activity than PLGA scaffolds. ${ }^{47}$ In a very recent study, Lock and Liu investigated the effects of nanohydroxyapatite, PLGA, and nanohydroxyapatite-PLGA composites on the functions of bone marrow-derived human mesenchymal stem cells in comparison with a short functional peptide of BMP7. For peptide DIF-7c loading, nanohydroxyapatite was functionalized by aminosilane chemistry (HA-Ps), whereas for the peptide-loaded nanocomposites (HA-Ps-PLGA), HA-Ps was dispersed in PLGA, as described elsewhere. ${ }^{12}$ To fabricate the PLGA scaffold with the peptide (PLGA-P) as a control, the peptide DIF-7c was dispersed directly in 
the PLGA matrix using the solvent casting method. Human mesenchymal stem cells from Lonza were cultured up to the second passage and seeded at a density of 5000 cells $/ \mathrm{cm}^{2}$ in mesenchymal stem cell growth medium into 12-well culture plates with the scaffolds and controls. The cells were cultured in mesenchymal stem cell growth medium for the first 6 days and, thereafter, in osteogenic induction media to induce osteogenesis. Osteogenic differentiation of human mesenchymal stem cells was studied in the nanocomposites and control scaffolds (HA-Ps-PLGA, HA-PLGA, PLGA-P, PLGA), on nanohydroxyapatite (with and without the DIF-7c peptide), on glass and PSTC references, as well as with direct injection of the DIF-7c peptide into the cell culture medium. Alkaline phosphatase is an enzyme, the production of which is associated with increased osteogenic differentiation of human mesenchymal stem cells, whereas calcium deposition represents the ultimate indicator of human mesenchymal stem cell differentiation. Both alkaline phosphatase activity and calcium deposition determinations after 40 days in culture demonstrated that nanophase hydroxyapatite and HA-PLGA nanocomposites can induce osteogenic differentiation of human mesenchymal stem cells, similar to the DIF-7c peptide. Moreover, DIF-7c peptide functionalization to nanohydroxyapatite and in nanocomposites did not show any significant effect in promoting adhesion or osteogenic differentiation of human mesenchymal stem cells when compared with nanohydroxyapatite and nanocomposites without the peptide. There was no detectable calcium deposition in the PLGA-P and PLGA scaffolds. However, when both the nanohydroxyapatite and the DIF-7c peptide were present in human mesenchymal stem cells culture, the enhancing effects of nanohydroxyapatite on osteogenic differentiation of human mesenchymal stem cells were more clearly pronounced than that of the DIF-7c peptide (Figure 2). These results support the use of HA-PLGA composites in promoting new bone growth without using expensive BMPs or BMP-derived peptides. However, their effects on human mesenchymal stem cell and bone tissue regeneration still need to be further studied in vivo for clinical translation. ${ }^{12}$

Their good bioinert and mechanical properties ${ }^{48,49}$ have promoted titanium and its alloys as some of the most widely used implants in the clinical setting. $\mathrm{TiO}_{2}$ nanotube layers were previously fabricated with controlled diameters by anodizing titanium in adequate electrolytes. ${ }^{37,50}$ Several studies demonstrated that $\mathrm{TiO}_{2}$ nanotubes of different diameters could affect the proliferation and differentiation of mesenchymal stem cells. ${ }^{37,51}$ For example, Park et al demonstrated that the nanoscale $\mathrm{TiO}_{2}$ surface topography significantly influences the vitality, proliferation, and motility of mesenchymal stem cells, as well as their differentiation into bone-forming cells, a specific response being noted for nanotubes with diameters between 15 and $100 \mathrm{~nm} .{ }^{51}$ For instance, the adhesion, proliferation, migration, and differentiation in mesenchymal stem cells were maximally induced on $15 \mathrm{~nm}$ nanotubes, but prevented on $100 \mathrm{~nm}$ nanotubes, which induced cell death (Table 1). Moreover, the response of freshly isolated hematopoietic stem cells from human umbilical cord blood with respect to differentiation into multinucleated osteoclasts showed the same size-dependent response to $\mathrm{TiO}_{2}$ nanotubes;

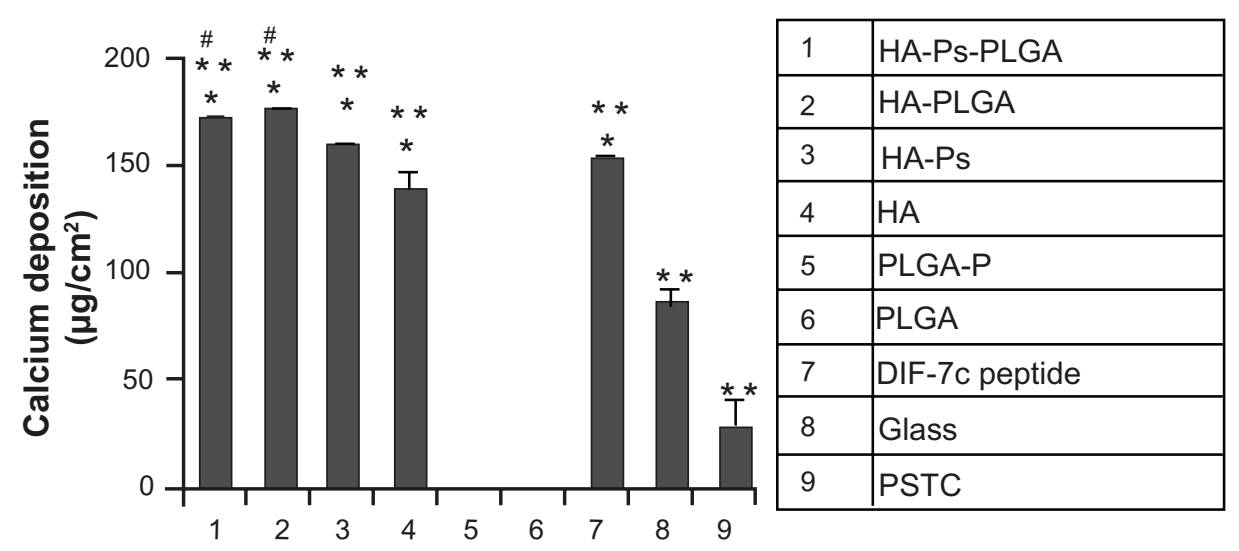

Figure 2 Osteogenic differentiation of human mesenchymal stem cells characterized by calcium deposition. The human mesenchymal stem cells were cultured with the materials as listed in the column.

Notes: Data are presented as the mean \pm standard error of the mean $(n=3)$. $* P<0.05$ compared with glass and PSTC ( 8 and 9); **P $<0.05$ compared with PLGA-P and PLGA (5 and 6); ${ }^{P}<0.05$ compared with DIF-7c peptide (7). Reprinted with permission Yang et al. ${ }^{6}$

Abbreviations: MSC, mesenchymal stem cells; HA, hydroxyapatite; PLGA, polylactide-co-glycolide; P, peptide; Ps, peptide loaded by aminosilane chemistry; HA-Ps, nano-HA loaded with peptide using aminosilane chemistry; PLGA-P, PLGA scaffold loaded with peptide; PTSC, polystyrene tissue culture plate; DIF-7c, peptide-derived short peptide. 
Table I Summary of the literature reports indicating applications of some nanomaterials in stem cell differentiation and proliferation

\begin{tabular}{|c|c|c|c|}
\hline Study & $\begin{array}{l}\text { Stem cell } \\
\text { population }\end{array}$ & Nanomaterial used & $\begin{array}{l}\text { Tissue cell type } \\
\text { generated }\end{array}$ \\
\hline Park et $\mathrm{al}^{37}$ & HUCB-HSCs & I5 $\mathrm{nm} \mathrm{TiO}{ }_{2}$ nanotubes & Osteoclasts \\
\hline Park et $\mathrm{al}^{37}$ & $\mathrm{HOBs}$ & $15 \mathrm{~nm} \mathrm{TiO}{ }_{2}$ nanotubes & Osteoblasts \\
\hline Elias et $\mathrm{al}^{54}$ & Osteoblasts & Nanometer diameter CNFs & $\begin{array}{l}\text { Enhances functions of } \\
\text { osteoblasts }\end{array}$ \\
\hline Nayak et $\mathrm{al}^{31}$ & HMSCs & $\begin{array}{l}\text { MWCNT-PEG (in the absence } \\
\text { of any additional growth factor) }\end{array}$ & Osteoblasts \\
\hline Lai et $\mathrm{al}^{50}$ & Rat BM-MSCs & $\begin{array}{l}\text { BMP2-functionalized } 30 \mathrm{~nm} \\
\text { (PDOP)- } \mathrm{TiO}_{2} \text { nanotubes }\end{array}$ & Osteoblasts \\
\hline Lock and Liu'12 & HBM-MSCs & $\begin{array}{l}\text { Nano-HA-PLGA composites; } \\
\text { nano-HA-Ps-PLGA; nano-HA-Ps }\end{array}$ & Osteogenic differentiation \\
\hline Li et al ${ }^{70}$ & $\begin{array}{l}\text { Myoblastic mouse } \\
\text { cells }(\mathrm{C} 2 \mathrm{Cl} 2)\end{array}$ & MWCNT compacts & Osteoblasts \\
\hline Namgung et al ${ }^{65}$ & HBM-MSCs & $\begin{array}{l}\text { Aligned CNT networks (without } \\
\text { osteogenic supplements) versus } \\
\text { randomly oriented CNT networks }\end{array}$ & $\begin{array}{l}\text { Enhances proliferation and } \\
\text { osteogenic differentiation } \\
\text { on aligned CNT networks }\end{array}$ \\
\hline Jan and Kotov ${ }^{71}$ & $\begin{array}{l}\text { Mouse embryonic } \\
\text { neural stem cells }\end{array}$ & $\begin{array}{l}\text { LBL-assembled SWNT-polyelectrolyte } \\
\text { composite }\end{array}$ & $\begin{array}{l}\text { Neurons, astrocytes, } \\
\text { oligodendrocytes }\end{array}$ \\
\hline Sridharan et al $7^{2}$ & HESCs & $\begin{array}{l}\text { Type I collagen/SWCNT composite } \\
\text { material }\end{array}$ & Neural progenitor cells \\
\hline Kam et $\mathrm{al}^{73}$ & Neural stem cells & SWCNT/laminin thin-film composite & Neurons, glial cells \\
\hline Chao et $\mathrm{a}^{74}$ & HESCs & PAA-g-CNTs 2D thin films & Neurons \\
\hline Chao et $\mathrm{a}^{75}$ & HESCs & PMAA-g-CNTs thin-film scaffolds & Neurons \\
\hline Tay et $\mathrm{al}^{84}$ & HMSCs & Carboxylated SWNT films & Neurons \\
\hline Andersen et $\mathrm{a}^{169}$ & HMSCs & $\begin{array}{l}\text { siRNA NP functionalization of } \\
\text { nanostructured scaffolds }\end{array}$ & $\begin{array}{l}\text { Osteogenic, adipogenic } \\
\text { differentiation: bone and fat cells }\end{array}$ \\
\hline Spadaccio et al ${ }^{77}$ & HMSCs & PLLA/HA nanocomposite & Chondrocyte-like cells \\
\hline $\begin{array}{l}\text { Tsukahara and } \\
\text { Haniu }^{78}\end{array}$ & $\begin{array}{l}\text { Myoblastic mouse } \\
\text { cells }(\mathrm{C} 2 \mathrm{Cl} 2)\end{array}$ & $\begin{array}{l}\text { Highly purified multiwall carbon } \\
\text { nanotube (HTT2800) }\end{array}$ & Adipose-like lineage \\
\hline Lee et $\mathrm{al}^{76}$ & $\begin{array}{l}\text { Mouse embryonic } \\
\text { fibroblasts }\end{array}$ & $\begin{array}{l}\text { Cationic polymer PEl-coated super } \\
\text { paramagnetic NP conjugated with plasmid } \\
\text { DNAs containing each of the iPS factor gene }\end{array}$ & $\begin{array}{l}\text { Exogenous DNA-free safe } \\
\text { iPS cell lines }\end{array}$ \\
\hline Ghaedi et $\mathrm{a}^{85}$ & HBM-MSCs & PLLA/collagen nanofiber scaffold & Hepatocyte-like cells \\
\hline
\end{tabular}

Abbreviations: HUCB-HSCs, human umbilical cord blood hematopoietic stem cells; HOBs, human osteoblast-like cells; HMSCs, human mesenchymal stem cells; MWCNTs, multiwalled carbon nanotubes; PEG, poly(ethylene glycol); BM-MSCs, bone marrow mesenchymal stem cells; HESCs, human embryonic stem cells; BMP2, bone morphogenetic protein 2; PDOP, polydopamine; HA, hydroxyapatite; nano-HA-PLGA, nano-HA-polylactide-co-glycolide; Ps-PLGA, polylactide-co-glycolide with peptide; SWCNTs, singlewalled carbon nanotubes; PAA-g-CNTs, PAA-poly(acrylic acid) grafted carbon nanotubes; PMAA-g-CNTs, PMAA-polymethacrylic acid grafted carbon nanotubes; SiRNA, small interfering RNA; iPS cells, induced pluripotent stem cell; PLLA/HA, PLLA-poly-L-lactic acid/hydroxyapatite; LBL, layer by layer.

differentiation to multinucleated and tartrate-resistant acid phosphatase-positive osteoclasts was significantly stimulated on nanotubes below $30 \mathrm{~nm}$ compared with smooth $\mathrm{TiO}_{2}$ surfaces. Similar to mesenchymal stem cells, cell proliferation of human osteoblast-like cells, as well as mineralization of human osteoblast-like cells and expression of osteogenic marker proteins, such as osteocalcin, were again highest on $15 \mathrm{~nm}$ nanotubes (Table 1), as compared with larger size nanotubes or smooth surfaces. However, what was interesting was that coculture with osteoclasts on $15 \mathrm{~nm}$ nanotubes did not impede osteogenic differentiation including mineralization, but the latter was not stimulated in coculture on $100 \mathrm{~nm}$ nanotubes. These results clearly indicate that the nanoscale microenvironment strongly controls bone cell differentiation by the interaction between osteoblasts and osteoclasts via cell-cell contacts and soluble factors from each cell type during coculture in vitro. The clustering of integrins into focal adhesion complexes and activation of intracellular signaling cascades into the nucleus and into the cytoskeleton mediate cell interactions with extracellular surfaces. ${ }^{52}$ It can be hypothesized that a spacing of 15-30 nm may result from the compact clustering of integrin receptor molecules with the actual size of the extracellular domain being about $10 \mathrm{~nm}$, into focal contacts by the $15 \mathrm{~nm}$ spacing of the nanotubes. This would explain the focal contact formation, cell proliferation, migration, and differentiation occurring at a higher rate on $15 \mathrm{~nm}$ nanotubes than on polished $\mathrm{TiO}_{2}$ or non-nanoporous surfaces. ${ }^{37,51,53}$

In another experiment, long-term osteoblast function was compared on fabricated carbon fiber compacts that were 
either nanophase (ie, dimensions $\leq 100 \mathrm{~nm}$ ) or conventional (ie, dimensions $>100 \mathrm{~nm}$ ). ${ }^{54}$ The authors showed that osteoblasts synthesized more alkaline phosphatase and deposited more extracellular calcium on the nanophase compacts than on the conventional compacts. It has been surprisingly noted among nanophase compacts that the higher the calcium content in the extracellular matrix, the lower the carbon fiber diameter. These results clearly show that osteoblast functions are significantly increased by carbon nanofibers, which were not functionalized with bioactive molecules, but, on the contrary, demonstrated novel properties in their raw state. ${ }^{42}$

Carbon nanotubes, with their unique physical and chemical properties are emerging as versatile tools in nanomedicine. ${ }^{31,55-57}$ It is widely known that the extracellular matrix can exert highly complex biochemical effects in a manner similar to that of growth factors (eg, BMP2), ${ }^{58}$ resulting in dramatic changes to cell phenotypes. In this context, Nayak et al conducted a study to research whether and how polyethylene glycol (PEG)-conjugated multiwalled carbon nanotubes (MWCNTs) can, as a composite biomaterial, promote osteogenic differentiation of human mesenchymal stem cells and simultaneous bone matrix mineralization in the absence of any biochemical inducer. Interestingly, both BMP2-treated substrates and MWCNT-PEG-coated (without BMP2) coverslips showed comparable cell differentiation into bone cells. Though no growth factors were added, MWCNT-PEG managed to transform human mesenchymal stem cells into bone-like cells successfully (Table 1). This has been demonstrated by multiple independent criteria at the transcript (eg, OPN), protein (eg, osteocalcin), and functional (eg, calcium deposition) levels showing that exposing mesenchymal stem cells to an appropriately selected biomaterial may induce cell differentiation into a targeted tissue type like osteoblasts. On the contrary, cells on the MWCNT-COOH substrates showed slightly irregular shapes, suggesting poor adherence to the substrate and thus lower cell growth (cell viability about 75\%). ${ }^{31}$ This is in agreement with an experiment by Liu et $\mathrm{a}^{59}$ in which carboxylated SWCNTs and MWCNTs inhibited cell proliferation and osteogenic differentiation of human mesenchymal stem cells, consequently demonstrating the potential cytotoxicity of carboxylated carbon nanotubes.

BMP2 has been demonstrated to promote osteogenesis when incorporated into hyaluronic acid hydrogels along with mesenchymal stem cells. ${ }^{60}$ Recently, Lai et al successfully fabricated surface-functionalized $\mathrm{TiO}_{2}$ nanotubes with BMP2 through the intermediate layer of polydopamine, which further promoted the osteogenic differentiation of mesenchymal stem cells (Table 1). Mesenchymal stem cells grown on BMP2-functionalized $\mathrm{TiO}_{2}$ nanotubes displayed higher expression of vinculin, an intracellular protein involved in linkage among cell adhesion membranous molecules, integrins, and actin filaments, and higher cell viabilities after 7 and 14 days of culture than those grown on native $\mathrm{TiO}_{2}$ nanotubes. Moreover, cell proliferation was affected not only by grafted BMP2 but also by the nanoscale surface topography. Thus, the growth tendency was higher for mesenchymal stem cells grown on native $\mathrm{TiO}_{2}$ nanotubes with diameters of $30 \mathrm{~nm}$ and $60 \mathrm{~nm}$ than that for mesenchymal stem cells grown on a titanium substrate and $100 \mathrm{~nm} \mathrm{TiO}_{2}$ nanotubes. Furthermore, the highest mineralization and highest alkaline phosphatase activity for all the groups were identified in mesenchymal stem cells cultured on BMP2-polydopamine $30 \mathrm{~nm} \mathrm{TiO}_{2}$ nanotubes. The approach described here can be applied in the development of titanium-based implants for enhanced bone osseointegration. ${ }^{50}$

While several studies have showed that differentiation of human mesenchymal stem cells is controlled simply by modulating the disorder or the dimension of nanostructures and the degree of differentiation in those cases was similar to that in the cases where soluble cues were used, ${ }^{61}$ it seems that the arrangement of individual carbon nanotubes, such as aligned carbon nanotube networks, is also critical to control the growth direction as well as differentiation of mesenchymal stem cells. ${ }^{62-64}$ The ability of human mesenchymal stem cells to identify individual carbon nanotubes in carbon nanotube networks and the fact that the growth and differentiation of these cells is affected by alignment of individual carbon nanotubes can account for the observed enhanced proliferation and osteogenic differentiation of human mesenchymal stem cells on aligned carbon nanotube networks compared with those on randomly oriented carbon nanotube networks. The upregulation of genes involved in the mechanotransduction pathways in human mesenchymal stem cells on aligned carbon nanotube networks supports the hypothesis that mechanotransduction pathways produced by the high cytoskeletal tension in elongated human mesenchymal stem cells on aligned carbon nanotube networks enhanced proliferation and osteogenic differentiation. ${ }^{65}$

In another in vitro study, Price et al tested the adhesion of osteoblasts, fibroblasts, chondrocytes, and smooth muscle cells on polycarbonate urethane/carbon nanofiber composite scaffolds. They found that composites with smaller-scale (ie, nanometer dimension) carbon fibers promoted osteoblast adhesion but did not promote adhesion of other cells. Surprisingly, smooth muscle cell, fibroblast, and chondrocyte 
adhesion decreased when the carbon nanofiber surface energy increased, suggesting that greater weight percentages of high surface energy carbon nanofibers in the polycarbonate urethane/carbon nanofiber composite increased osteoblast adhesion while, at the same time decreasing fibroblast adhesion. This can only prove that surface energy has a big influence on cell adhesion and subsequent cell functions. ${ }^{66}$

Small interfering RNAs (siRNAs) can silence synthesis of a specific protein by base pairing with its mRNA sequence when introduced into cells ${ }^{67}$ and, therefore, be very likely candidates in the genetic treatment of cancer, as demonstrated also by Wu et al, who used PEG-polyethyleneimine (PEI) as a non-viral carrier of siRNA targeting CD44v6 in gastric carcinoma cells. ${ }^{68}$ The first example of an siRNA nanoparticle-functionalized scaffold able to regulate stem cell differentiation was developed by Andersen et al. ${ }^{69}$ Adipogenesis and osteogenesis are two oppositely regulated pathways, and differentiation enhancers are known to downregulate genes relating to the opposite pathway. Consequently, these researchers showed that specific targeting of TRIB2 and Bcl2-L2 on implants in vitro and in vivo leads to enhanced adipogenic and osteogenic differentiation from human mesenchymal stem cells, respectively, in specific locations within the same implant by placing different siRNA in distinct locations. Moreover, it appears that siBCL2L2 and siTRIB2 can initiate early osteogenic and adipogenic differentiation, respectively, as demonstrated by in vivo findings (Figure 3 ). However, they cannot induce terminal differentiation as the sole differentiation cue. Importantly, the nanostructured nature of the scaffolds enables nanoparticle retention and localization of different siRNAs to distinct parts of an implant. This made it possible to guide stem cells into alternate differentiation in specified locations. Therefore, this method is very likely to become an efficient and realistic strategy to engineer tissues and organs that contain multiple cell types. ${ }^{69}$

\section{Chondrogenic differentiation}

Because mature articular cartilage cannot heal spontaneously due to its low mitotic activity, the search for a cell type capable of both repopulating tissue loss and reconstituting the connective environment crucial for cartilage function is required. The role of hydroxyapatite and tricalcium phosphate in facilitating and promoting cartilage regeneration ${ }^{79,80}$ and biomineralization in cartilage has been demonstrated. Scaffolds, the pivotal structure of engineered tissue, set the environment for neoextracellular matrix synthesis. The scaffold component is expected to lead the process of tissue development by supporting cell colonization, migration, growth, and differentiation. The process of electrospinning the poly-L-lactic acid (PLLA)/hydroxyapatite system, obtained by dispersing nanopowders of hydroxyapatite in a PLLA solution, was employed to fabricate hybrid PLLAhydroxyapatite membranes. Consequently, Spadaccio et al tested the putative chondrogenic differentiation of human mesenchymal stem cells following culture on a hydroxyapatite-functionalized scaffold. After 14 days of culture, cells positive for the chondrogenic transcription factor, SOX-9, could be detected in the PLLA-hydroxyapatite nanocomposite in a significantly greater percentage than in the PLLA scaffold. Although limited by the lack of quantitative data on mRNA expression of chondrogenic markers to be able to speculate on the actual degree of differentiation obtained, the experiment managed to demonstrate that electrospun PLLA-hydroxyapatite nanocomposites can induce differentiation of human mesenchymal stem cells into chondrocyte-like cells that produce a proteoglycan-based matrix $^{77}$ (Table 1).

\section{Other cell lines}

\section{Adipose-like cell differentiation}

Myoblastic mouse cells (C2C12) are a well established and commonly used in vitro model for the study of myogenic differentiation. ${ }^{81}$ They have been shown to have pluripotent mesenchymal precursor cell characteristics. Tsukahara et $\mathrm{al}^{78}$ tested the ability of one of the most highly purified MWCNTs (HTT2800) to modulate the proliferation and differentiation of the skeletal muscle cell line, $\mathrm{C} 2 \mathrm{C} 12$. The major finding of this study was that HTT2800 greatly influenced intracellular lipid accumulation in $\mathrm{C} 2 \mathrm{C} 12$ cells. Moreover, quantified polymerase chain reaction analysis showed that expression of adipose-related genes was markedly upregulated during HTT2800 exposure (Table 1), whereas expression of musclespecific genes (myogenin, MyoD) was reduced. Overall, these findings demonstrate, for the first time, that HTT2800 promotes the transition from a myogenic lineage to an adiposelike lineage, partly determined by CD36 overexpression. ${ }^{78}$

\section{Osteogenic differentiation}

In myoblastic mouse cell $\mathrm{C} 2 \mathrm{C} 12$ cultures, cell attachment, proliferation, and differentiation was shown to be better on MWCNT compacts than on graphite compacts. Moreover, the alkaline phosphatase activity in $\mathrm{C} 2 \mathrm{C} 12$ cells on MWCNTs was also significantly higher than on graphite, and this supports the idea that MWCNTs are responsible for inducing $\mathrm{C} 2 \mathrm{C} 12$ cell differentiation into osteogenic cells to a greater 


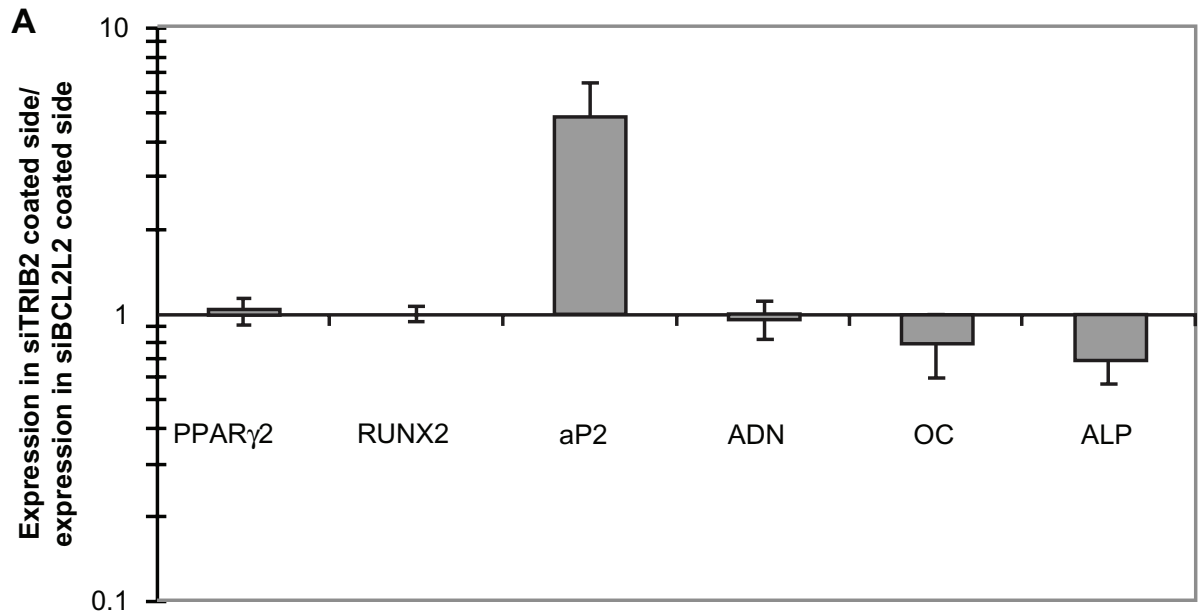

B

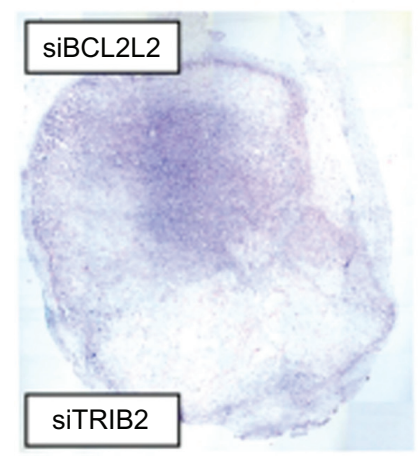

C

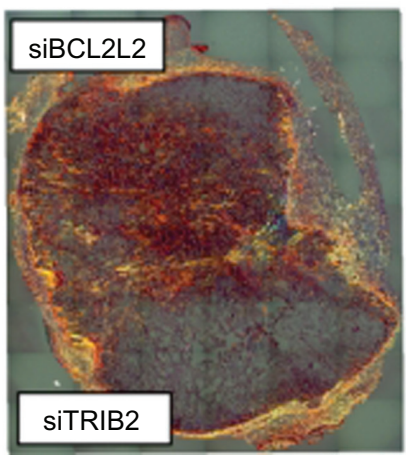

D

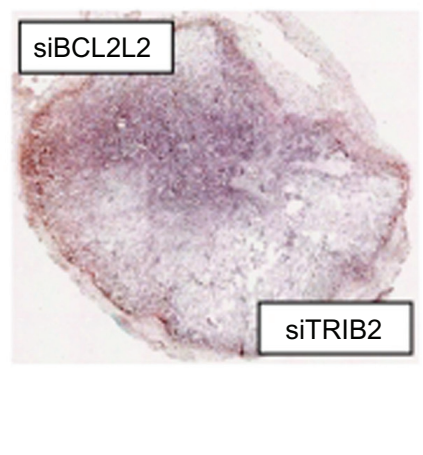

Figure 3 In vitro and in vivo double differentiation of human mesenchymal stem cells (EGFP negative) seeded on scaffolds where one side was coated with TranslTTKO nanoparticles containing TRIB2-targeted siRNA (\#I) and the other side with TransIT-TKO nanoparticles containing BCL2L2-targeted siRNA (\#I). (A) In vitro double differentiation. The dual-coated scaffolds were seeded with human mesenchymal stem cells and cultured for 2 days in maintenance medium and 8 days in complex medium. The sides were then separated and for each side the ratios of the mRNA levels of PPAR 2, RUNX2, AP2, ADN, OC and alkaline phosphatase relative to the mRNA level of B2M were determined. The ratios of the marker expression between the side with the TRIB2-targeted siRNA (\#I) and the side with the BCL2L2-targeted siRNA (\#I) were characterized and plotted. Averages are graphed with error bars representing standard deviation $(n=3$ or 4$)$. The $y$-axis is logarithmic and the markers that were upregulated on the side coated with TRIB2-targeted siRNA compared with the side coated with BCL2L2-targeted siRNA will have values above I and vice versa. (B-D) In vivo differentiation on a dual-coated scaffold. The dual-coated scaffolds were seeded with human mesenchymal stem cells for 16 hours in maintenance medium. They were then implanted subcutaneously in non-obese diabetic/severe combined immunodeficient mice for 2 weeks, after which they were surgically removed and studied by histology. Whole scaffold sections were stained with (B) hematoxylin and eosin, (C) Sirius red, and (D) von Kossa. Mosaic pictures of whole scaffold sections at $\times 10$ magnification are displayed with the BCL2L2 siRNA-coated side in the top of the pictures, host tissue can be seen surrounding the implant. On the Sirius red-stained section, collagen deposition appears red and birefringence appears orange. Images in $(\mathbf{B})$ and $(\mathbf{C})$ are $7.6 \mathrm{~mm}$ wide and $8.4 \mathrm{~mm}$ high, and $(\mathbf{D})$ is $7.6 \mathrm{~mm}$ wide and $6.5 \mathrm{~mm}$ high. Reprinted with permission from Andersen et al. ${ }^{69}$

Abbreviations: ADN, adiponectin; ALP, alkaline phosphatase; AP2, apolipoprotein 2; B2M, $\beta-2$ microglobulin; COLI, collagen type I; EGFP, enhanced green fluorescent protein; LPL, lipoprotein lipase; OC, osteocalcin; PPAR $\gamma 2$, peroxisome proliferator-activated receptor- $\gamma$ isoform 2; siRNA, small-interfering RNA.

extent than graphite and that MWCNTs can be considered to be an osteoproductive material. ${ }^{70}$

\section{Differentiation into non-mesenchymal neural cell and hepatocyte-like lineages}

Valuable insight into the way in which carbon nanotubes influence neuronal cell differentiation can be crucial in developing new applications, such as improved cell culture substrates, neural probe coatings, and nerve guidance conduits. ${ }^{65}$ The central nervous system has a very poor regenerative potential and is difficult to access. This partly explains why neurological diseases including stroke and neurodegenerative disorders such as Parkinson's disease, Alzheimer's disease, and Huntington's disease which typically result from irrevocable damage and improper functioning of specialized neuronal cells often lack appropriate therapies. Neural disease is currently among the complicated and significant clinical problems in the world, with around $250,000-400,000$ people being reported to live with a spinal cord injury and 13,000 additional people suffering spinal cord injuries each year in the United States. More and more neural implants will be needed as the population increases and ages. However, compared with other tissues (such as bone tissue), operations of repairing damaged nerves 
and their full recovery are hampered by the complexity of nervous system anatomy and function. ${ }^{42}$ Over the last decade, the potential for therapeutic use of stem cell transplantation for cell replacement or as cellular vectors for gene delivery in neurometabolic and neurodegenerative diseases has received a great deal of interest. The interaction between stem cells and extracellular microenvironment plays an important role in controlling stem cell differentiation via chemical, electrical, and physical signals. The diameter and length of carbon nanotubes has been shown to be similar to those of extracellular matrix molecules, such as collagens and laminins, known to enhance neuron growth. Therefore, carbon nanotubes have also been extensively studied for biomedical applications due to their excellent mechanical strength, flexibility, and conductivity. ${ }^{74,75}$ Carbon nanotubes are able to maintain the structural integrity of the scaffolds during cell growth and differentiation and have demonstrated effects similar to other various biomaterial substrates which promote neural differentiation of stem cells. ${ }^{82}$ On the other hand, the ability of stem cells to differentiate into various cell types, including neurons, makes them an important element for regenerative medicine to be used in the treatment of various neurological disorders. ${ }^{42}$

\section{Mesenchymal stem cells}

Depending on the local microenvironment, mesenchymal stem cells have the ability to differentiate into several specific cell lineages. ${ }^{83}$ Tay et al examined how carboxylated SWCNT films influenced the behavior of mesenchymal stem cells in the absence of a specific differentiation medium. ${ }^{84}$ Mesenchymal stem cells spread and proliferated on SWCNT films, and neurogenic markers were upregulated, while osteogenic markers remained low. Distribution of focal adhesion was more homogenous in cells grown on the SWCNT surface, compared with controls grown on glass. The conclusion of this study was that mesenchymal stem cell differentiation seems to be influenced by the nanotopography provided by carbon nanotubes. ${ }^{82}$

Furthermore, very recently, a nanofibrous scaffold composed of PLLA and collagen, fabricated by the electrospinning technique, proved to be a matrix conducive to the differentiation of human bone marrow-derived mesenchymal stem cells into functional hepatocyte-like cells. Importantly, the expression levels of liver-specific markers, such as albumin, $\alpha$-fetoprotein, and cytokeratins 8 and 18, and the secretion of liver functioning serum proteins, albumin and $\alpha-1$ antitrypsin, into the culture medium were higher in differentiated cells on the nanofibers than when they were cultured on plates, demonstrating that the nanofibrous scaffolds promoted and enhanced human bone marrow mesenchymal stem cell differentiation into a hepatocyte lineage ${ }^{85}$ (Table 1). Although the results of the experiment conducted by Ghaedi et al must be confirmed by future researchers, their observations might represent the first step for the use of this nanofibrous scaffold for culture and differentiation of stem cells that may be used in tissue engineering and for the treatment of liver failure.

\section{Neural stem cells}

Neural stem cells have the ability to differentiate into neurons and glial cells. Hence, mouse embryonic neural stem cells from the cortex were successfully differentiated into neurons, astrocytes as well as oligodeendrocytes on layerby-layer assembled SWNT-polyelectrolyte multilayer thin films. Biocompatibility, neurite outgrowth, and expression of neural markers were similar to those differentiated on poly-L-ornithine, a standard substratum commonly used for neuron culture. ${ }^{71}$ However, differences could be noted after a 7-day period of culture because the composites selectively promoted more neurons and fewer astrocytes than the common poly-L-ornithine substrate used for neural studies. The results proved that PEI-functionalized SWCNTs were cytocompatible for stem cell growth and that they play an important role in differentiating stem cells into neuronal cells $^{42}$ (Table 1).

In a study conducted by Kam et al on the influence of SWCNTs on the effects of laminin films on neural stem cell cultures, ${ }^{73}$ laminin-SWCNT films proved to support the growth and proliferation of neural stem cells and trigger longer outgrowths as compared with pure laminin substrates. Moreover, the study also showed that layer-by-layer films consisting of SWCNTs and laminin can serve as a biocompatible substrate for promoting adhesion and differentiation as well as for mediating electrical stimulation of neuronal cell lines. Neural stem cells precursors could still be identified 7 days post-seeding on the heat-treated SWCNT-laminin substrate (Figure 4). However, protein marker expression (microtubule-associated protein 2, glial fibrillary acidic protein) showed the presence of large amounts of differentiated neurons and glial cells, due to spontaneous differentiation likely caused by the physical properties of the SWCNT-laminin composites. These results are a proof of the fact that thin composite SWCNT-laminin films can be employed as materials in the foundation of neural electrodes with a chemical structure better adapted to long-term integration with neural tissue. 

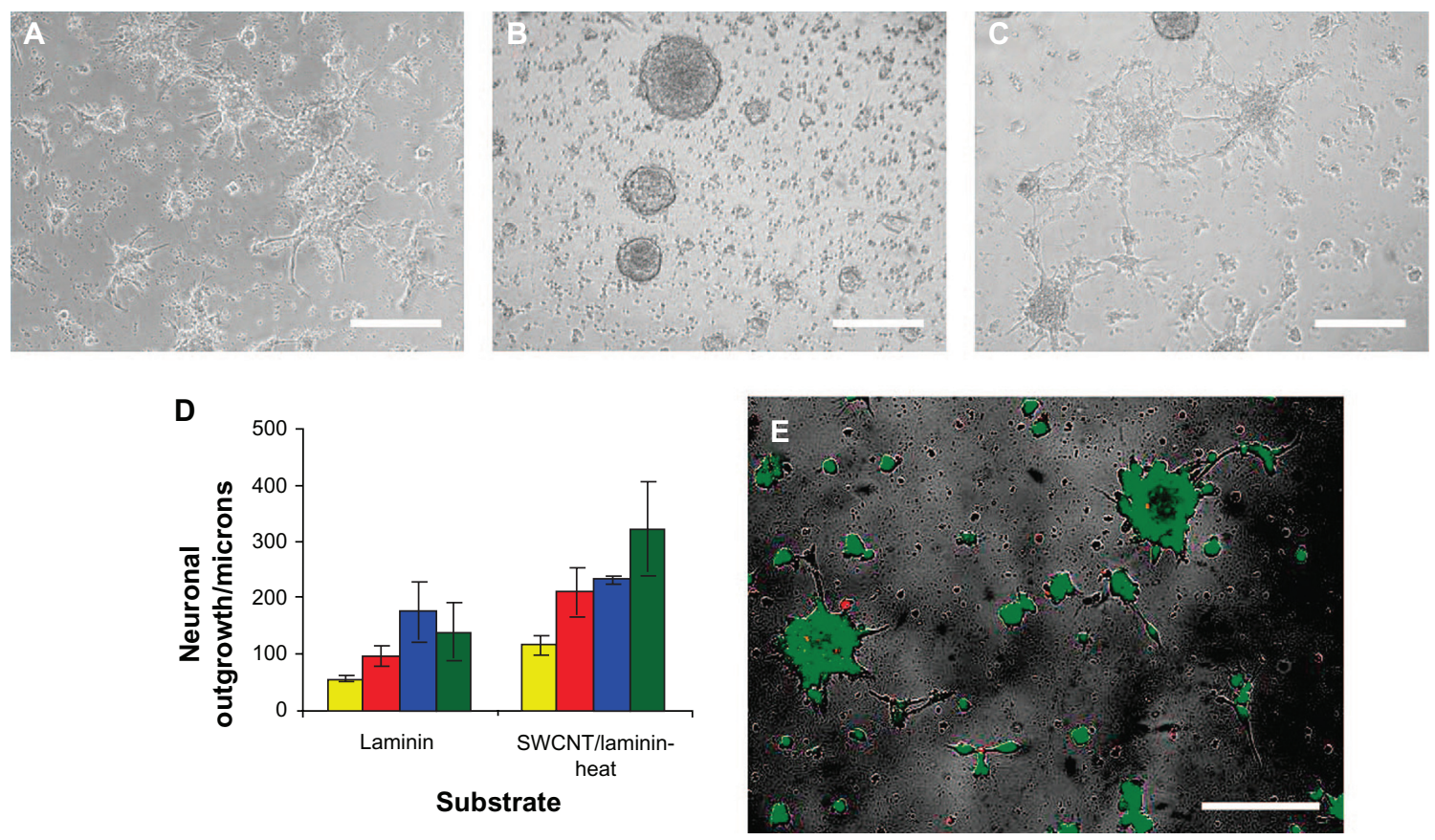

Figure 4 Micrograph assessing NSC cell adhesion and differentiation 72 hours after initial seeding on (A) laminin-coated glass slides and on 10 bilayered thin SWCNT-laminin films that were (B) used as is or (C) heated at $300^{\circ} \mathrm{C}$ for 10 minutes. (D) Distance of outgrowth from neurospheres after 24 hours (yellow), 48 hours (red), 72 hours (blue), and I 20 hours (green) on laminin-coated slides and heat-treated SWCNT-laminin film on slide. (E) Live-dead viability assay on seeded cells where live cells are stained green and dead cells are red.

Note: Scale bars are $200 \mu \mathrm{m}$. Reprinted with permission Kam NWS, Jan E, Kotov NA. Electrical stimulation of neural stem cells mediated by humanized carbon nanotube composite made with extracellular matrix protein. Nano Lett. 2008;9(I):273-278. Copyright 2008 American Chemical Society.

Abbreviations: NSC, neural stem cells; SWCNTs, single-walled carbon nanotubes.

\section{Human embryonic stem cells}

Human embryonic stem cells are able to differentiate into almost all cell types according to regulated spatial and temporal signals. Therefore, human embryonic stem cells possess the potential to provide a nearly unlimited supply of cell types and are extremely promising for regenerative medicine and cell-based transplantation therapy in many neurological and neurodegenerative diseases. ${ }^{86}$

Sridharan et $\mathrm{al}^{72}$ explored the use of a composite collagencarbon nanotube material as an in vitro cell culture matrix to direct the early differentiation of human embryonic stem cells to neural progenitor cells. It is known that type I collagen, as an extracellular matrix protein, intensifies the growth of many neuronal cell types ${ }^{87}$ as well as the neural differentiation of human embryonic stem cells in a neural differentiation medium. ${ }^{88}$ Carboxyl-modified SWCNTs were used to obtain a composite material with type I collagen, the stiffness and structure of which proved to be greatly influenced by carbon nanotubes (Figure 5). This resulted in the early differentiation of more than $90 \%$ of the cells into nestin-positive cells, likely to be neural progenitor cells (Table 1). Additionally, ectodermal cell-specific long filaments also resulted from the process of culturing embryonic stem cells on collagen-SWCNT gels.
The physical changes induced by adding SWCNTs to the collagen film account for the increased degree of differentiation and provide insight into how carbon nanotubes can impact the behavior of progenitor and stem cells. ${ }^{89}$

Polyacrylic acid (PAA) is a weak acid and has a negative effect on neuron differentiation and neuronal cell attachment. ${ }^{90}$ However, the same PAA grafted onto carbon nanotubes has been demonstrated to have a strong ability to differentiate human embryonic stem cells into neurons. Therefore, the branches identified on the differentiated neurons in the new two-dimensional thin film composed of PAA grafted onto carbon nanotubes are more numerous, and this indicates that these differentiated neurons were more mature than those on pure PAA control surfaces, which produced lower levels of neural differentiation. Furthermore, this new type of thin-film scaffold enhances embryonic stem cell growth and increases cell adhesion in comparison with conventional polyL-ornithine surfaces, as well as pure PAA control surfaces. Surface analysis and cell adhesion studies have demonstrated the role played by carbon nanotube-based scaffolds in increasing protein adsorption and cell attachment. This makes carbon nanotube-based materials into excellent candidates for human embryonic stem cells' neuron differentiation. ${ }^{74}$ 

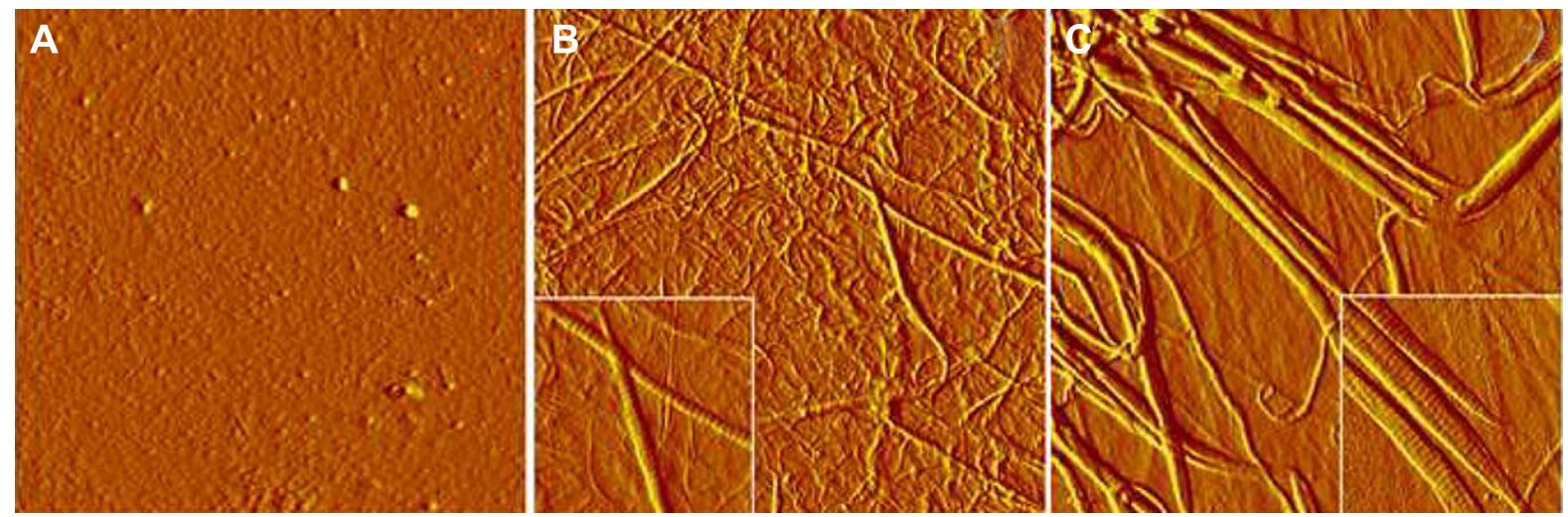

Figure 5 Atomic force microscopy characterization (amplitude images) of the surface structures of gelatin (A), collagen (B), and collagen/carbon nanotubes (C) matrices prepared under the cell culture conditions.

Note: Image size, $8.5 \times 8.5 \mu \mathrm{m}^{2}$, inset $2 \times 2 \mu \mathrm{m}^{2}$. Reprinted with permission from Sridharan et al..$^{89}$

The same group performed a follow-up study on the ability of PAA-grafted MWCNTs, pure MWCNTs, as well as MWCNTs functionalized with polymethacrylic acid (PMAA $^{75}$ to promote differentiation of human embryonic stem cells into neuronal cells, using poly-L-ornithine as a reference. The results of the study strongly sustain the ability of carbon nanotube-based nanofibrillar surfaces, having enhanced cell adhesion and growth factor adsorption similar to the extracellular matrix, to boost stem cell differentiation. The highest nitrogen content was identified for the surfaces coated with PMAA-functionalized MWCNTs. There are two cues that account for the strong affinity to proteins: a physical topographical cue, ie, the combination of large surface area and nanoscale grooves given by carbon nanotubes, and a chemical one, respectively, the less acidic and more hydrophobic environment provided by PMAA functionalization. PMAA-coated surfaces demonstrated better embryoid body adhesion and higher yield of neuronal cells differentiated from embryoid bodies when PMAA was compared with PAA, proving, thus, the significant role played by surface chemistry in cell adhesion. The highest density of neuronal cells has been generated by surfaces coated with PMAA-grafted carbon nanotubes, the value of which was even higher than that of poly-L-ornithine. This is in agreement with recent reports demonstrating that the adhesion of neuronal cells is regulated by roughened surface. ${ }^{91}$ Therefore, it can be concluded that human embryonic stem cells can directly provide relatively mature neuronal cells when these new polymer-grafted carbon nanotube thin-film scaffolds are used, because they assure the appropriate microenvironment, with physical and chemical cues that enable direct attachment and differentiation of human embryonic stem cell colonies. $^{75}$

\section{Other applications of nanomaterials in stem cell differentiation \\ Induced pluripotent stem cells}

Modern regenerative medicine has been targeting the generation of patient-specific induced pluripotent stem (iPS) cell lines ${ }^{92}$ but has been facing the technological problem of using potentially harmful genome-integrating viral DNAs, which might lead to oncogenesis. Moreover, several recent high profile publications have demonstrated that iPSC lines can retain both genetic and epigenetic "memories" of the differentiated cell from which they were derived. ${ }^{93}$ Hence, a number of challenges need to be addressed in order to effectively use these cell lines for disease modeling and for stem cell transplantation. Such challenges include the low efficiency of iPS cell generation without genetic alterations, the possibility of tumor formation in vivo, the random integration of retroviral-based delivery vectors into the genome, and the unregulated growth of the remaining cells that are partially reprogrammed and refractory to differentiation. ${ }^{94}$ The great interest in generating human iPS cells without permanent genetic alterations has prompted a group of researchers to publish a schematic representation of the various causes and possible safeguards regarding human iPSC genomic instability. ${ }^{95}$ Very recently, Lee et $\mathrm{al}^{76}$ generated iPS cells using a non-viral magnetic nanoparticle-based transfection method. Biodegradable cationic polymer PEI-coated super paramagnetic nanoparticles were complexed to plasmid DNAs which comprised each of the four iPS factor genes. The complex was exposed to the magnetic forces that guide gene vectors for all nucleic acid transfection toward normal mouse embryonic fibroblasts. Results of dynamic light scattering analysis and transmission electron microscopic analyses showed efficient conjugation of nanoparticles with iPS genes. Transfection 
was followed by nanofection-mediated iPS cells exhibiting embryonic stem cell-like characteristics, such as expression of endogenous pluripotency genes, differentiation of three germ layer lineages (endoderm, mesoderm, ectoderm) and formation of teratomas. Of particular interest, more than $60 \%$ of the iPS cells produced were not integrated with exogenous plasmid DNAs. The conclusion of their study was that nonviral magnet-based nanofection of iPS genes resulted in threefold higher efficiencies of exogenous DNA-free safe iPS cell line production, compared with results from other groups that exhibit behavior patterns similar to those of embryonic stem cells in various aspects. ${ }^{76}$

\section{Conclusion}

Although research in medicine and technology has reached peaks seemingly unattainable before, there still are incurable diseases that not only hamper quality of life but can also lead to death. Engineering of tissues and organs that contain multiple cell types (eg, pancreas) might become an efficient and realistic strategy for the treatment of incurable diseases in the near future. Tissue engineering, imaging, and drug delivery is a promising field that has been developing intensely due to the rapid progress in nanotechnology as well as in stem cell research. Scaffold functionalization tuned to each specific application and cell response is a recent trend in tissue engineering. Improving the cellular response, creating an appropriate nanobiointerface, and the loading and delivery of drugs or bioactive molecules as well as enhancing the bioactivity of the scaffolds can lead to optimization of nanofibrous materials for transplantation and clinical application. However, further research is needed to elucidate the biological impact of nanoparticles on stem cells.

\section{Acknowledgments}

The authors would like to acknowledge grant support from the Romanian Ministry of Research (PN-II-RU-PD-2011-30287 and PN-II-RU-TE-2011-3-0251).

\section{Disclosure}

The authors report no conflicts of interest in this work.

\section{References}

1. Nelson TJ, Ge ZD, Van Orman J, et al. Improved cardiac function in infarcted mice after treatment with pluripotent embryonic stem cells. Anat Rec A Discov Mol Cell Evol Biol. 2006;288(11):1216-1224.

2. Fan CG, Zhang Q, Zhou J. Therapeutic potentials of mesenchymal stem cells derived from human umbilical cord. Stem Cell Rev. 2011;7(1): 195-207.

3. Pittenger MF, Mackay AM, Beck SC, et al. Multilineage potential of adult human mesenchymal stem cells. Science. 1999;284(5411): 143-147.
4. Iancu C, Ilie I, Mocan L, et al. Human cord blood-derived stem cells in transplantation and regenerative medicine. In: A Gholamrezanezhad, editor. Stem Cells in Clinic and Research. Rijeka: InTech; 2011: 21-58.

5. Malgieri A, Kantzari E, Patrizi MP, Gambardella S. Bone marrow and umbilical cord blood human mesenchymal stem cells: state of the art. Int J Clin Exp Med. 2010;3(4):248-269.

6. Yang CC, Shih YH, Ko MH, Hsu SY, Cheng H, Fu YS. Transplantation of human umbilical mesenchymal stem cells from Wharton's jelly after complete transection of the rat spinal cord. PLoS One. 2008;3(10):e3336.

7. Rossignol J, Boyer C, Lévêque X, Dunbar GL, Lescaudron L. Mesenchymal stem cell transplants reduce behavioral deficits in the 3-nitropropionic rat model of Huntington's disease. Cell Transplant. 2009;18:233.

8. Martin-Rendon E, Sweeney D, Lu F, Girdlestone J, Navarrete C, Watt SM. 5-Azacytidine-treated human mesenchymal stem/progenitor cells derived from umbilical cord, cord blood and bone marrow do not generate cardiomyocytes in vitro at high frequencies. Vox Sang. 2008;95(2):137-148.

9. Roura S, Farré J, Hove-Madsen L, et al. Exposure to cardiomyogenic stimuli fails to transdifferentiate human umbilical cord blood-derived mesenchymal stem cells. Basic Res Cardiol. 2010;105(3):419-430.

10. Wang HW, Lin LM, He HY, et al. Human umbilical cord mesenchymal stem cells derived from Wharton's jelly differentiate into insulinproducing cells in vitro. Chin Med J. 2011;124(10):1534-1539.

11. Tolar J, Nauta AJ, Osborn MJ, et al. Sarcoma derived from cultured mesenchymal stem cells. Stem Cells. 2007;25(2):371-379.

12. Lock J, Liu H. Nanomaterials enhance osteogenic differentiation of human mesenchymal stem cells similar to a short peptide of BMP-7. Int J Nanomedicine. 2011;6:2769-2777.

13. Nel AE, Mädler L, Velegol D, et al. Understanding biophysicochemical interactions at the nano-bio interface. Nat Mater. 2009;8(7): 543-557.

14. Wan ACA, Ying JY. Nanomaterials for in situ cell delivery and tissue regeneration. Adv Drug Deliv Rev. 2010;62(7-8):731-740.

15. Orza A, Soritau O, Olenic L, et al. Electrically conductive goldcoated collagen nanofibers for placental-derived mesenchymal stem cells enhanced differentiation and proliferation. ACS Nano. 2011;5(6):4490-4503.

16. Iancu C, Ilie IR, Georgescu CE, et al. Applications of nanomaterials in cell stem therapies and the onset of nanomedicine. Particul Sci Technol. 2009;27(6):562-574.

17. Ruggiero A, Villa CH, Holland JP, et al. Imaging and treating tumor vasculature with targeted radiolabeled carbon nanotubes. Int $J$ Nanomedicine. 2010;5:783-802.

18. Khazaei A, Rad MNS, Borazjani MK. Organic functionalization of single-walled carbon nanotubes (SWCNTs) with some chemotherapeutic agents as a potential method for drug delivery. Int J Nanomedicine. 2010;5:639-645.

19. Kutsuzawa K, Akaike T, Chowdhury EH. The influence of the celladhesive proteins E-cadherin and fibronectin embedded in carbonateapatite DNA carrier on transgene delivery and expression in a mouse embryonic stem cell line. Biomaterials. 2008;29(3):370-376.

20. Ferreira L, Squier T, Park H, Choe H, Kohane DS, Langer R. Human embryoid bodies containing nano- and microparticulate delivery vehicles. Adv Mater. 2008;20(12):2285-2291.

21. Ahrens ET, Flores R, Xu H, Morel PA. In vivo imaging platform for tracking immunotherapeutic cells. Nat Biotechnol. 2005;23(8):983-987.

22. Green JJ, Zhou BY, Mitalipova MM, et al. Nanoparticles for gene transfer to human embryonic stem cell colonies. Nano Lett. 2008;8(10):3126-3130.

23. Rosen AB, Kelly DJ, Schuldt AJT, et al. Finding fluorescent needles in the cardiac haystack: tracking human mesenchymal stem cells labeled with quantum dots for quantitative in vivo three-dimensional fluorescence analysis. Stem Cells. 2007;25(8):2128-2138.

24. Mooney E, Dockery P, Greiser U, Murphy M, Barron V. Carbon nanotubes and mesenchymal stem cells: biocompatibility, proliferation and differentiation. Nano Lett. 2008;8(8):2137-2143. 
25. Ferreira L. Nanoparticles as tools to study and control stem cells. $J$ Cell Biochem. 2009;108(4):746-752.

26. Chen XA, Zhang LJ, He ZJ, et al. Plasmid-encapsulated polyethylene glycol-grafted polyethylenimine nanoparticles for gene delivery into rat mesenchymal stem cells. Int J Nanomedicine. 2011;6:843-853.

27. Kim SE, Jeon O, Lee JB, et al. Enhancement of ectopic bone formation by bone morphogenetic protein-2 delivery using heparin-conjugated PLGA nanoparticles with transplantation of bone marrow-derived mesenchymal stem cells. J Biomed Sci. 2008;15(6):771-777.

28. Hosseinkhani H, Hosseinkhani M, Gabrielson NP, Pack DW, Khademhosseini A, Kobayashi H. DNA nanoparticles encapsulated in 3D tissue-engineered scaffolds enhance osteogenic differentiation of mesenchymal stem cells. J Biomed Mater Res A . 2008;85(1):47-60.

29. Yang X, Walboomers XF, van den Dolder J, et al. Non-viral bone morphogenetic protein 2 transfection of rat dental pulp stem cells using calcium phosphate nanoparticles as carriers. Tissue Eng Part A. 2008;14(1):71-81.

30. Dyke CA, James M. Unbundled and highly functionalized carbon nanotubes from aqueous reactions. Nano Lett. 2003;3(9):1215-1218.

31. Nayak TR, Jian L, Phua LC, Ho HK, Ren Y, Pastorin G. Thin films of functionalized multiwalled carbon nanotubes as suitable scaffold materials for stem cells proliferation and bone formation. ACS Nano. 2010;4(12):7717-7725.

32. Sheyn D, Kallai I, Tawackoli W, et al. Gene-modified adult stem cells regenerate vertebral bone defect in a rat model. Mol Pharm. 2011;8(5):1592-1601.

33. Bruder SP, Fink DJ, Caplan AI. Mesenchymal stem cells in bone development, bone repair, and skeletal regenaration therapy. $J$ Cell Biochem. 1994;56(3):283-294.

34. Arien-Zakay H, Lazarovici P, Nagler A. Tissue regeneration potential in human umbilical cord blood. Best Pract Res Clin Haematol. 2010;23(2):291-303.

35. Lavery K, Hawley S, Swain P, Rooney R, Falb D, Alaoui-Ismaili MH. New insights into BMP-7 mediated osteoblastic differentiation of primary human mesenchymal stem cells. Bone. 2009;45(1):27-41.

36. Spadaccio C, Rainer A, Trombetta M, et al. Poly-L-lactic acid/hydroxyapatite electrospun nanocomposites induce chondrogenic differentiation of human MSC. Ann Biomed Eng. 2009;37(7):1376-1389.

37. Park J, Bauer S, Schlegel KA, Neukam FW, von der Mark K, Schmuki P. $\mathrm{TiO}_{2}$ nanotube surfaces: $15 \mathrm{~nm}$ - an optimal length scale of surface topography for cell adhesion and differentiation. Small. 2009;5(6):666-671.

38. Thostenson ET, Chou TW. Aligned multi-walled carbon nanotubereinforced composites: processing and mechanical characterization. J Phys D: Appl Phys. 2002;35:L77-L80.

39. Cadek M, Coleman J, Barron V, Hedicke K, Blau W. Morphological and mechanical properties of carbon-nanotube-reinforced semicrystalline and amorphous polymer composites. Appl Phys Lett. 2002; $81: 5123$.

40. Shi X, Hudson JL, Spicer PP, Tour JM, Krishnamoorti R, Mikos AG. Rheological behaviour and mechanical characterization of injectable poly (propylene fumarate)/single-walled carbon nanotube composites for bone tissue engineering. Nanotechnology. 2005;16:S531.

41. Balani K, Anderson R, Laha T, et al. Plasma-sprayed carbon nanotube reinforced hydroxyapatite coatings and their interaction with human osteoblasts in vitro. Biomaterials. 2007;28(4):618-624.

42. Tran PA, Zhang L, Webster TJ. Carbon nanofibers and carbon nanotubes in regenerative medicine. Adv Drug Deliv Rev. 2009;61(12): 1097-1114

43. Zhao B, Hu H, Mandal SK, Haddon RC. A bone mimic based on the self-assembly of hydroxyapatite on chemically functionalized single-walled carbon nanotubes. Chem Mater. 2005;17(12): 3235-3241.

44. Shi X, Hudson JL, Spicer PP, James M, Krishnamoorti R, Mikos AG. Injectable nanocomposites of single-walled carbon nanotubes and biodegradable polymers for bone tissue engineering. Biomacromolecules. 2006;7(7):2237-2242.
45. Schiller C, Epple M. Carbonated calcium phosphates are suitable $\mathrm{pH}$-stabilising fillers for biodegradable polyesters. Biomaterials. 2003;24(12):2037-2043.

46. Liu H, Slamovich EB, Webster TJ. Less harmful acidic degradation of poly (lactic-co-glycolic acid) bone tissue engineering scaffolds through titania nanoparticle addition. Int J Nanomedicine. 2006;1(4):541-545.

47. Huang Y, Ren J, Chen C, Ren T, Zhou X. Preparation and properties of poly (lactide-co-glycolide)(PLGA)/nano-hydroxyapatite (NHA) scaffolds by thermally induced phase separation and rabbit MSCs culture on scaffolds. J Biomater Appl. 2008;22(5):409-432.

48. Ballo A, Agheli H, Lausmaa J, Thomsen P, Petronis S. Nanostructured model implants for in vivo studies: influence of well-defined nanotopography on de novo bone formation on titanium implants. Int $J$ Nanomedicine. 2011;6:3415-3428.

49. Gongadze E, Kabaso D, Bauer S, et al. Adhesion of osteoblasts to a nanorough titanium implant surface. Int $J$ Nanomedicine. 2011;6:1801-1816.

50. Lai M, Cai K, Zhao L, Chen X, Hou Y, Yang Z. Surface functionalization of $\mathrm{TiO}_{2}$ nanotubes with bone morphogenetic protein 2 and its synergistic effect on the differentiation of mesenchymal stem cells. Biomacromolecules. 2011;12(4):1097-1105.

51. Park J, Bauer S, von der Mark K, Schmuki P. Nanosize and vitality: $\mathrm{TiO}_{2}$ nanotube diameter directs cell fate. Nano Lett. 2007;7(6): $1686-1691$.

52. Giancotti FG. A structural view of integrin activation and signaling. Dev Cell. 2003;4(2):149-151.

53. Takagi J, Petre BM, Walz T, Springer TA. Global conformational rearrangements in integrin extracellular domains in outside-in and inside-out signaling. Cell. 2002;110(5):599-611.

54. Elias KL, Price RL, Webster TJ. Enhanced functions of osteoblasts on nanometer diameter carbon fibers. Biomaterials. 2002;23(15): 3279-3287.

55. Iancu C, Mocan L. Advances in cancer therapy through the use of carbon nanotube-mediated targeted hyperthermia. Int J Nanomedicine. 2011;6:1675-1684.

56. Ruggiero A, Villa $\mathrm{CH}$, Holland JP, et al. Imaging and treating tumor vasculature with targeted radiolabeled carbon nanotubes. Int $J$ Nanomedicine. 2010;5:783-802.

57. Mocan T, Iancu C. Effective colon cancer prophylaxis in mice using embryonic stem cells and carbon nanotubes. Int $J$ Nanomedicine. 2011;6:1945-1954.

58. Hidalgo-Bastida LA, Cartmell SH. Mesenchymal stem cells, osteoblasts and extracellular matrix proteins: enhancing cell adhesion and differentiation for bone tissue engineering. Tissue Eng Part B Rev. 2010;16(4):405-412.

59. Liu D, Yi C, Zhang D, Zhang J, Yang M. Inhibition of proliferation and differentiation of mesenchymal stem cells by carboxylated carbon nanotubes. ACS Nano. 2010;4(4):2185-2195.

60. Kim J, Kim IS, Cho TH, et al. Bone regeneration using hyaluronic acid-based hydrogel with bone morphogenic protein-2 and human mesenchymal stem cells. Biomaterials. 2007;28(10):1830-1837.

61. Oh S, Brammer KS, Li Y, et al. Stem cell fate dictated solely by altered nanotube dimension. Proc Natl Acad Sci U S A. 2009;106(7): 2130-2135.

62. Dang JM, Leong KW. Myogenic induction of aligned mesenchymal stem cell sheets by culture on thermally responsive electrospun nanofibers. Adv Mater. 2007;19(19):2775-2779.

63. Lee MR, Kwon KW, Jung H, et al. Direct differentiation of human embryonic stem cells into selective neurons on nanoscale ridge/groove pattern arrays. Biomaterials. 2010;31(15):4360-4366.

64. Yim EKF, Darling EM, Kulangara K, Guilak F, Leong KW. Nanotopography-induced changes in focal adhesions, cytoskeletal organization, and mechanical properties of human mesenchymal stem cells. Biomaterials. 2010;31(6):1299-1306.

65. Namgung S, Baik KY, Park J, Hong S. Controlling the growth and differentiation of human mesenchymal stem cells by the arrangement of individual carbon nanotubes. ACS Nano. 2011;5(9):7383-7390. 
66. Price RL, Waid MC, Haberstroh KM, Webster TJ. Selective bone cell adhesion on formulations containing carbon nanofibers. Biomaterials. 2003;24(11):1877-1887.

67. Tijsterman M, Plasterk RHA. Dicers at RISC: the mechanism of RNAi. Cell. 2004;117(1):1-3.

68. Wu Y, Wang W, Chen Y, et al. The investigation of polymer-siRNA nanoparticle for gene therapy of gastric cancer in vitro. Int J Nanomedicine. 2010;5:129-136.

69. Andersen MØ, Nygaard JV, Burns JS, et al. siRNA nanoparticle functionalization of nanostructured scaffolds enables controlled multilineage differentiation of stem cells. Mol Ther. 2010;18(11):2018-2027.

70. Li X, Gao H, Uo M, et al. Effect of carbon nanotubes on cellular functions in vitro. J Biomed Mater Res A. 2009;91(1):132-139.

71. Jan E, Kotov NA. Successful differentiation of mouse neural stem cells on layer-by-layer assembled single-walled carbon nanotube composite. Nano Lett. 2007;7(5):1123-1128.

72. Sridharan I, Kim T, Wang R. Adapting collagen/CNT matrix in directing hESC differentiation. Biochem Biophys Res Commun. 2009;381(4):508-512.

73. Kam NWS, Jan E, Kotov NA. Electrical stimulation of neural stem cells mediated by humanized carbon nanotube composite made with extracellular matrix protein. Nano Lett. 2008;9(1):273-278.

74. Chao TI, Xiang S, Chen CS, et al. Carbon nanotubes promote neuron differentiation from human embryonic stem cells. Biochem Biophys Res Commun. 2009;384(4):426-430.

75. Chao TI, Xiang S, Lipstate JF, Wang C, Lu J. Poly (methacrylic acid)grafted carbon nanotube scaffolds enhance differentiation of hESCs into neuronal cells. Adv Mater. 2010;22(32):3542-3547.

76. Lee CH, Kim JH, Lee HJ, et al. The generation of iPS cells using non-viral magnetic nanoparticle-based transfection. Biomaterials. 2011;32(28):6683-6691.

77. Spadaccio C, Rainer A, Trombetta M, et al. Poly-L-lactic acid/hydroxyapatite electrospun nanocomposites induce chondrogenic differentiation of human MSC. Ann Biomed Eng. 2009;37(7):1376-1389.

78. Tsukahara T, Haniu H. Nanoparticle-mediated intracellular lipid accumulation during $\mathrm{C} 2 \mathrm{C} 12$ cell differentiation. Biochem Biophys Res Commun. 2011;406(4):558-563.

79. Pilliar R, Kandel R, Grynpas M, Zalzal P, Hurtig M. Osteochondral defect repair using a novel tissue engineering approach: sheep model study. Technol Health Care. 2007;15(1):47-56.

80. Ito Y, Adachi N, Nakamae A, Yanada S, Ochi M. Transplantation of tissue-engineered osteochondral plug using cultured chondrocytes and interconnected porous calcium hydroxyapatite ceramic cylindrical plugs to treat osteochondral defects in a rabbit model. Artif Organs. 2008;32(1):36-44.
81. Koh GY, Klug MG, Soonpaa MH, Field LJ. Differentiation and long-term survival of $\mathrm{C} 2 \mathrm{C} 12$ myoblast grafts in heart. J Clin Invest. 1993;92(3):1548-1554.

82. Voge CM, Stegemann JP. Carbon nanotubes in neural interfacing applications. J Neural Eng. 2011;8:011001.

83. Lund AW, Yener B, Stegemann JP, Plopper GE. The natural and engineered 3D microenvironment as a regulatory cue during stem cell fate determination. Tissue Eng Part B Rev. 2009;15(3):371-380.

84. Tay CY, Gu H, Leong WS, et al. Cellular behavior of human mesenchymal stem cells cultured on single-walled carbon nanotube film. Carbon. 2010;48(4):1095-1104.

85. Ghaedi M, Soleimani M, Shabani I, Duan Y, Lotfi AS. Hepatic differentiation from human mesenchymal stem cells on a novel nanofiber scaffold. Cell Mol Biol Lett. 2012;17(1):89-106.

86. Schuldiner M, Eiges R, Eden A, et al. Induced neuronal differentiation of human embryonic stem cells. Brain Res. 2001;913(2):201-205.

87. Lin HJ, O’Shaughnessy TJ, Kelly J, Ma W. Neural stem cell differentiation in a cell-collagen-bioreactor culture system. Dev Brain Res. 2004;153(2):163-173

88. Ma W, Tavakoli T, Derby E, Serebryakova Y, Rao M, Mattson M. Cell-extracellular matrix interactions regulate neural differentiation of human embryonic stem cells. BMC Dev Biol. 2008;8(1):90.

89. Sridharan I, Kim T, Wang R. Adapting collagen/CNT matrix in directing hESC differentiation. Biochem Biophys Res Commun. 2009;381(4):508-512.

90. Li B, Ma Y, Wang S, Moran PM. Influence of carboxyl group density on neuron cell attachment and differentiation behavior: gradient-guided neurite outgrowth. Biomaterials. 2005;26(24):4956-4963.

91. Dekeyser C, Zuyderhoff E, Giuliano R, Federoff H, Dupont-Gillain CC, Rouxhet P. A rough morphology of the adsorbed fibronectin layer favors adhesion of neuronal cells. J Biomed Mater Res A. 2008;87(1): 116-128.

92. Deng W. Induced pluripotent stem cells: paths to new medicines. EMBO Rep. 2010;11(3):161-165.

93. Orlando L, Sanchez-Ripoll Y, Foster J, Bone H, Giachino C, Welham MJ. Differential coupling of self-renewal signaling pathways in murine induced pluripotent stem cells. PloS One. 2012;7(1):e30234.

94. Madonna R. Human-induced pluripotent stem cells: in quest of clinical applications. Mol Biotechnol. 2012. Epub Feb 3.

95. Ben-David U, Benvenisty N, Mayshar Y. Genetic instability in human induced pluripotent stem cells: classification of causes and possible safeguards. Cell Cycle. 2010;9(23):4603-4604.
International Journal of Nanomedicine

\section{Publish your work in this journal}

The International Journal of Nanomedicine is an international, peerreviewed journal focusing on the application of nanotechnology in diagnostics, therapeutics, and drug delivery systems throughout the biomedical field. This journal is indexed on PubMed Central,

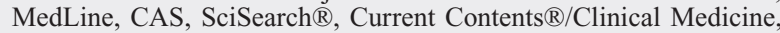

\section{Dovepress}

Journal Citation Reports/Science Edition, EMBase, Scopus and the Elsevier Bibliographic databases. The manuscript management system is completely online and includes a very quick and fair peer-review system, which is all easy to use. Visit http://www.dovepress.com/ testimonials.php to read real quotes from published authors. 